\title{
The diversity of locally utilized plants and local botanical knowledge in Central Bengkulu District, Bengkulu Province, Indonesia
}

\author{
WIRYONO ${ }^{\boldsymbol{\nu}}$, JAPRIYANTO, ERNIWATI \\ Department of Forestry, Faculty of Agriculture, University of Bengkulu. Jl. WR Supratman, Bengkulu, Indonesia. Tel./Fax. +62-736-21170, "email: \\ wiryonogood@unib.ac.id, wiryonogood@yahoo.com
}

Manuscript received: 9 September 2017. Revision accepted: 8 October 2017.

\begin{abstract}
Wiryono, Japriyanto, Erniwati. 2017. The diversity of locally utilized plants and local botanical knowledge in Central Bengkulu District, Bengkulu Province, Indonesia. Biodiversitas 18: 1589-1595. For thousands of years rural communities have derived from their surrounding plants many products to meet their daily life. Maintaining botanical knowledge is, therefore, essential for the sustainability of rural communities. The objectives of this study were to know the diversity of plants utilized by villagers in Tanjung Terdana Village, Central Bengkulu District, Indonesia, and to describe the botanical knowledge of the villagers. Data were collected through interview with two key informants and 64 respondents. The results showed that 75 of plant species were used by villagers for ten purposes, namely medicine (53 species), firewood (41), food (32), construction (23), ornament (8), handycraft (6), hedge (6), custom (6) forage (3), and food coloring (1). On average, respondents could identify $70 \%$ of the 50 plants shown to them, and almost all respondents $(98 \%)$ could identify plants for food. Older respondents spent more time in garden and knew more plant names and uses than the younger ones. Gender or time spent in electronic entertainment did not affect the botanical knowledge. Respondents unfinishing elementary school knew more plants than those finishing schools, may be because they were older. This study implied that activities in the garden can maintain the local botanical knowledge.
\end{abstract}

Keywords: Biodiversity, ethnobotany, traditional ecological knowledge

\section{INTRODUCTION}

In rural areas, plants provide daily needs as well marketable products that may generate income for communities. For example, villagers in Batu Ampar Village of South Bengkulu District used 83 plant species for eight purposes (Wiryono and Lipranto 2013), in Harapan Makmur Village of Central Bengkulu District, 79 species for ten purposes (Wiryono et al. 2016), and in Banten 163 species for nine purposes (Wardah 2003).

The use of plants for food may be the most important one for human survival, followed by the use for medicine. Searching for food and other basic necessities in the environment for thousands of years, human has accumulated knowledge of local plants, animals and their physical environment and this knowledge is passed from generation to generation (Pilgrim et al. 2008). This knowledge is called traditional ecological knowledge or local ecological knowledge (hereafter referred to as TEK or LEK).

Essential for the survival of human, TEK is currently under threat of modernization. Studies show that older generation fails to pass TEK to the younger generation in many parts of the world (Quinlan and Quinlan 2007; Sousa et al. 2012; Saynez-Vaquest et al. 2016). With modernization young people may be allienated from their environment and consequently lose their knowledge of nature. In the US, the visit to nature parks decreased drastically due to the emergence of electronic entertainment, such as video games and the internet
(Pergams and Zaradic 2006). In Mexico, the children of Zapotecs who attended school had little TEK because they did not have enough time to accompany their parents collecting traditional plants and the language used in school was different from that used for TEK (Saynez-Vaquez et al. 2016), while in Doñana, Spain, farmers lost their TEK due to market integration and mechanization and intensification of agriculture, so that the farmers abandoned their traditional farming (Gómez-Baggethun and Reyes-Garcia 2013)

There have been many concerns for the preservation of TEK and integrate it in the management and conservation of natural resources (Drew and Henne 2006; Charnley et al 2007). It is encouraging that some studies showed that some communities managed to preserve their TEK despite cultural changes they experienced. In New York, migrants from the Dominican Republic maintained their knowledge of their traditional food medicines because they still consumed them (Vandebroek and Balick 2012). In Bolivia, the Tsimane' managed to maintain their TEK because it was still the basis of their livelyhood and they still practiced farming and sold products in traditional way (Gómez-Baggethun and Reyes-Garcia 2013).

In Sumatera, economic development has caused the conversion of natural forest into single-species plantation, mainly oil palm (Saxon and Roquemore 2011). The disappearing of tropical forest has caused the loss of biodiversity and botanical knowledge among indigenous people, so it is important to document this knowledge in order to slow or reverse the loss of it (Ramirez 2007). The 
objectives of this study were to know the diversity of plants utilized by villagers in Central Bengkulu District, Bengkulu Province, Indonesia, and to know the ability of villagers to identify plants and their uses.

\section{MATERIALS AND METHODS}

\section{Location and time of study}

The study was conducted in Tanjung Terdana Village, Pondok Kubang Sub-district, Central Bengkulu District, Bengkulu Province, Sumatra Island, Indonesia (Figure 1). Data collection was done in February-March, 2012. The study site is a lowland area with altitude of $20-30 \mathrm{~m}$ above sea level. The climate is wet tropical, with average annual rainfall of $2500-4000 \mathrm{~mm}$ and temperature of $25-27^{\circ} \mathrm{C}$. The total residents of the villagers was 606 , mostly native to the area, belonging to Lembak tribe who worked as farmers. The settlement is adjacent to state forest area, but there has been land tenurial conflict in the forest area, and most of the forest area has been cleared and cultivated with agricultural crops by villagers.

\section{Data collection}

Step 1. Selecting key informants and gathering data of utilized plants

To know the plants commonly used by the villagers, two key informants were choosen to be interviewed. They were traditional medicine men in the village who had good knowledge of local plants and their uses. Using key informants for gathering data is commonly done in ethnobotany study (Tongco 2007). They were taken to the field to show the plants and their uses. Each plant was photographed and the local name and uses were recorded in tally sheets. Identification of plants was done using photographs as well as plant specimens. A total of 75 plant species were identified as useful for villagers.

\section{Step 2. Selecting plants to be shown to respondents}

Of the 75 species used by villagers, a total of 50 species commonly found in the field were selected and their images were printed. Each plant was represented by two or more pictures showing the whole plant and a close-up showing the characteristics of the plant.

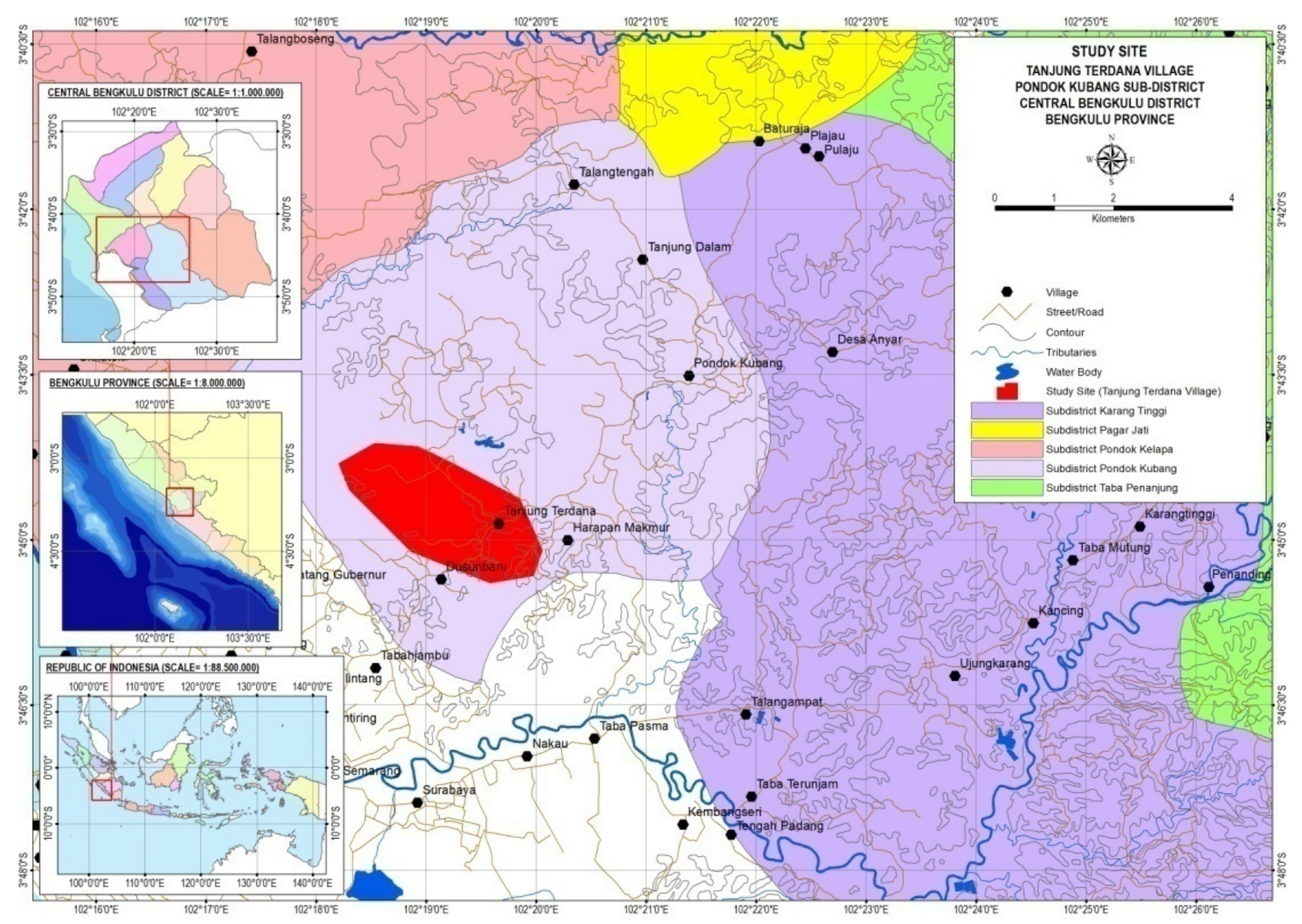

Figure 1. Location of study, Tanjung Terdana Village, colored red on the map, Pondok Kubang Sub-district, Central Bengkulu District, Bengkulu Province, Indonesia 


\section{Step 3. Selecting respondents}

A total of 64 respondents, consisting of 32 males and 32 females, were selected from the total of 606 villagers, 15 64 years old. From each age class, with 5-year interval, approximately $10 \%$ was selected as respondents, except for the elderly whose population was very small; they were represented by $20 \%$ samples.

\section{Step 4. Interviewing respondents}

Each respondent was interviewed to gather their personal data, namely age, gender, family profession, education, hobby, time spent in garden (field), and time spent enjoying electronic entertaiment (watching TV, video, playing video games). Then, each photograph of the selected plants was shown to them to identify its name and uses. Photographs have been used successfully by Setalaphruk and Price (2007), Pilgrim et al. (2008) and Wiryono and Nurliana (2011) to test the ability of respondents to recognize plants.

\section{Data analysis}

All data were tabulated and analyzed descriptively. To determine whether gender affected the knowledge of plant names and uses, t-tests were conducted. Stepwise multiple regressions were done to know the correlation between knowledge of plant names and uses (dependent variables) and three other variables, namely age of respondents, the length of time they spent for electronic entertainment, and the length of time they spent in garden (independent variables). Simple regressions were done to know the correlation between age and time spent in garden, between use values and the identifiability of plants, and between knowledge of plants and knowledge of plants uses. The statistical analyses were done using statistical software SPSS, except for t-tests which were done using Excel. Family profession was not tested because $91 \%$ of respondents were farmers. Education data did not fit for a statistical test, so they were tabulated and averaged.

The usefulness (use value) of each species according to respondents was calculated using this formula (Albuquerque et al. 2006).

$$
\mathrm{UV}=(\Sigma \mathrm{Ui}) / \mathrm{n}
$$

Whereby, Ui is the number of uses of a given species mentioned by each respondent and $\mathrm{n}$ is the total number of respondents.

\section{RESULTS AND DISCUSSION}

\section{Diversity of locally used plants}

A total of 75 plant species from 39 families were recognized by key informants as having been used by villagers for ten purposes (Figure 2 and Table 1). Most of the plants were trees (48 species), followed by shrub (14), herb (5), palm (4), climber and grass (2 species each). Medicinal use had the highest number of plant species (53), followed by firewood (41), food (32), construction (23), and ornament (8). Handycraft, hedge and custom uses had the same number of species, which was 6 , while 3 species could be used for forage and one species for food coloring.

The number of plants used by villagers in this study was fewer than that used by villagers in Batu Ampar, South Bengkulu District, which was 83 species (Wiryono and Lipranto 2013), in Harapan Makmur Village, Central Bengkulu District, 79 species (Wiryono et al. 2016), and in Banten, 163 species (Wardah 2003). However, it was higher than 41 species used by villagers in Keramat Mulya, Soreang District of West Java (Okubo et al. 2010) and 65 species in Kabena Island, Southeast Celebes Province (Rahayu and Rugayah 2010). The high diversity of utilized species shown by the key informants reflected the high diversity of plants growing in the village and the wide knowledge of the key informants of the plants.

It is not surprising that the highest number of plant use was for medicines because the key informants in this study were medicine men. The number of plants for medicine in this study was higher than 47 species used in Rajegwesi Village, Banyuwangi District, East Java (Pamungkas et al. 2013), 33 species in Mamuju, in West Sulawesi (Syamsiah et al. 2016) and 45 species in Seram Island, Molluccas (Susiarti 2015), but lower than 127 species by Serampas tribe, Jambi Province (Hariyadi and Ticktin 2012). Serampas tribe is indigenous people living in the border of Kerinci Seblat National Park who still practices traditional life. In many parts of the world, despite the advance of biomedicine, traditional medicine is still used (Rathore et al. 2015; Zank and Hanazaki 2017).

Among the 75 species used by villagers, key informants mentioned coconut as having the highest uses (6), followed by bamboo (5). Correspondingly, the determination of use value from the respondents'answer showed that these two species had the highest use values, but bamboo being the number one (2.7) and coconut second (2.5). Similarly, these two species were also the most important useful species, in Batu Ampar village, Bengkulu Province (Wiryono and Lipranto 2013). In Rajegwesi Village, Banyuwangi, East Java Province (Pamungkas et al. 2013) coconut also had the highest cultural important value, but bamboo didn't.

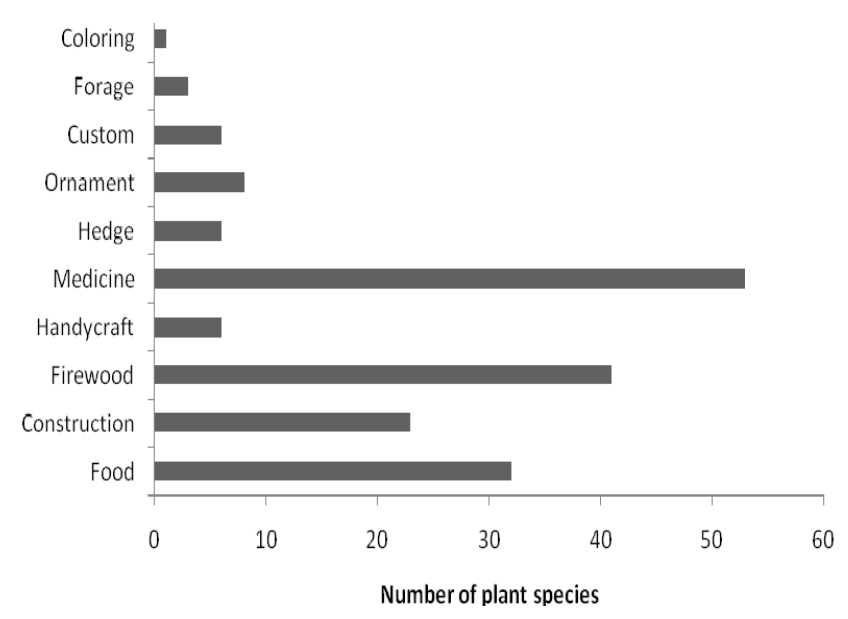

Figure 2. The number of plant species for each type of use 
Table 1. The diversity of locally utilized plants and local botanical knowledge in Central Bengkulu District, Bengkulu Province, Indonesia

\begin{tabular}{|c|c|c|c|c|c|c|c|}
\hline Local names & Scientific names & Family & $\begin{array}{l}\text { Growth } \\
\text { form }\end{array}$ & Types of use & $\begin{array}{l}\text { Total } \\
\text { uses }\end{array}$ & $\begin{array}{l}\text { Use } \\
\text { value }\end{array}$ & $\begin{array}{l}\text { \% identi- } \\
\text { fication }\end{array}$ \\
\hline Bambu & Bambusa sp. & Poaceae & Grass & $\begin{array}{l}\text { Construction, custom, firewood, } \\
\text { food, handycraft, hedge }\end{array}$ & 5 & 2.7 & 100 \\
\hline Kelapa hijau & Cocos nucifera Var. Viridis. & Arecaceae & Palm & $\begin{array}{l}\text { Construction, custom, firewood, } \\
\text { food, handycraft, medicine }\end{array}$ & 6 & 2.5 & 100 \\
\hline Durian & Durio zibetinus L. & Malvaceae & Tree & Construction, firewood, food & 3 & 2.3 & 97 \\
\hline Mangga & Mangifera indica $\mathrm{L}$. & Anacardiaceae & Tree & $\begin{array}{l}\text { Construction, firewood, food, } \\
\text { forage }\end{array}$ & 4 & 2.2 & 100 \\
\hline Jering/Jengkol & $\begin{array}{l}\text { Archidendron pauciflorum (Benth) } \\
\text { I.C. Nielsen }\end{array}$ & Fabaceae & Tree & $\begin{array}{l}\text { Construction, firewood, food, } \\
\text { medicine }\end{array}$ & 4 & 2.0 & 95 \\
\hline Sirsak & Annona muricata $\mathrm{L}$ & Annonaceae & Tree & Firewood, food, medicine & 3 & 1.8 & 100 \\
\hline Manggis & Garcinia mangostana L. & Clusiaceae & Tree & Firewood, food medicine & 3 & 1.7 & 92 \\
\hline Bangka/Pinang & Areca catechu L. & Arecaceae & Palm & Custom, food, hedge, medicine & 4 & 1.5 & 98 \\
\hline Kapuk & Ceiba pentandra L. Gaertn. & Bombacaceae & Tree & $\begin{array}{l}\text { Construction, firewood, hedge, } \\
\text { medicine }\end{array}$ & 4 & 1.5 & 77 \\
\hline $\begin{array}{l}\text { Belimbing } \\
\text { wuluh/Besi }\end{array}$ & Averrhoa bilimbi $\mathrm{L}$. & Oxalidaceae & Tree & Food, medicine & 2 & 1.4 & 97 \\
\hline Jambu biji & Psidium guajava $\mathrm{L}$ & Myrtaceae & Tree & Food, medicine & 2 & 1.4 & 97 \\
\hline Kayu gadis & $\begin{array}{l}\text { Cinnamomum parthenoxylon (Jack) } \\
\text { Meisn. }\end{array}$ & Lauraceae & Tree & Construction, firewood, medicine & 3 & 1.3 & 81 \\
\hline Tebu Hitam & Saccharum officinarum $\mathrm{L}$. & Poaceae & Grass & Food, medicine & 2 & 1.3 & 100 \\
\hline Terap/Lantung & $\begin{array}{l}\text { Artocarpus elasticus Reinwe. Ex. } \\
\text { Blume }\end{array}$ & Moraceae & Tree & Construction, firewood, hedge & 3 & 1.3 & 70 \\
\hline Langsat & Lansium domesticum. & Meliaceae & Tree & Firewood, food & 2 & 1.2 & 86 \\
\hline Nangka & Artocarpus heterophyllus Lam. & Moraceae & Tree & $\begin{array}{l}\text { Construction, firewood, food, } \\
\text { forage }\end{array}$ & 4 & 1.2 & 100 \\
\hline $\begin{array}{l}\text { Keduruk/Sendud } \\
\text { uk }\end{array}$ & Melastoma malabahtricum L. & Melastomaceae & Shrub & Firewood, food, medicine & 3 & 1.1 & 91 \\
\hline Sungkai & Peronema canescens Jack. & Verbenaceae & Tree & Construction, firewood, medicine & 3 & 1.1 & 84 \\
\hline Bungo rayo & Hibiscus rosa-sinensis $\mathrm{L}$. & Malvaceae & Tree & Hedge, medicine, ornament & 3 & 1.1 & 87 \\
\hline Jeruk purut & Citrus hystrix D.C. & Rutaceae & Tree & Food, medicine & 2 & 1.1 & 98 \\
\hline Jeruk nipis & $\begin{array}{l}\text { Citrus aurantifolia (Christm.) } \\
\text { Swingle. }\end{array}$ & Rutaceae & Tree & Food, medicine & 2 & 1.0 & 95 \\
\hline Lengkuas & Alpinia galanga (L.) Wild. & Zingiberaceae & Herb & Food, medicine & 2 & 1.0 & 91 \\
\hline Jarak pagar & Jatropha curcas L. & Euphorbiaceae & Shrub & Hedge, medicine & 3 & 1.0 & 97 \\
\hline Sedingin & Kalanchoe pinnata (Lam.) Pers. & Crassulaceae & Shrub & Medicine, ornament & 2 & 1.0 & 92 \\
\hline Tegang/Rimbang & Solanum torvum $\mathrm{Sw}$. & Solanaceae & Shrub & Food, medicine, & 2 & 1.0 & 97 \\
\hline Pandan Wangi & Pandanus amaryllifolius Roxb. & Pandanaceae & Shrub & Coloring, custom, ornament & 3 & 0.9 & 92 \\
\hline Rumput Malesia & $\begin{array}{l}\text { Chromolaena odorata (L.) R.M.King } \\
\text { \&.H.Rob }\end{array}$ & Asteraceae & Shrub & Medicine & 1 & 0.9 & 94 \\
\hline Gelinggang & Senna alata (L.) Roxb. & Fabaceae & Shrub & Medicine & 1 & 0.9 & 89 \\
\hline Pulai/Plawi & Alstonia scholaris (L.) R.Br. & Apocynaceae & Tree & Construction, firewood, medicine & 4 & 0.9 & 81 \\
\hline Nilau & Commersonia bartramia (L.) Merr. & Malvaceae & Tree & Construction, firewood, hedge & 3 & 0.8 & 45 \\
\hline Rambutan & Nephelium lappaceum L. & Sapindaceae & Tree & $\begin{array}{l}\text { Construction, firewood, food, } \\
\text { medicine }\end{array}$ & 4 & 0.8 & 67 \\
\hline Kayu Kapung & $\begin{array}{l}\text { Oroxylum indicum (L.) Benth. ex } \\
\text { Kurz }\end{array}$ & Bignoniaceae & Tree & Firewood, medicine & 2 & 0.7 & 70 \\
\hline Merampuyan & Rhodamnia cinerea Jack. & Myrtaceae & Tree & Construction, firewood, medicine & 3 & 0.7 & 55 \\
\hline Capo/Sembung & Blumea balsamifera (L). DC. & Asteraceae & Tree & Medicine & 1 & 0.7 & 67 \\
\hline Pelangas & Aporosa dioica (Roxb.) Müll.Arg. & Phyllanthaceae & Tree & Construction, firewood & 2 & 0.7 & 45 \\
\hline Tukup bumi & Elephantopus scaber L. & Asteraceae & Herb & Medicine & 1 & 0.7 & 67 \\
\hline Simpur & $\begin{array}{l}\text { Dillenia excelsa (Jack.) Martelli ex } \\
\text { Gilg }\end{array}$ & Dilleniaceae & Tree & Firewood, medicine & 2 & 0.6 & 53 \\
\hline Kenidai & Bridelia monoica (Lour.) Merr & Phyllanthaceae & Tree & Firewood, medicine & 2 & 0.5 & 30 \\
\hline Salung & $\begin{array}{l}\text { Psychotria viridiflora Reinw ex } \\
\text { Blume }\end{array}$ & Rubiaceae & Shrub & Firewood, medicine & 2 & 0.5 & 52 \\
\hline Inai kayu & Lawsonia inermis L. & Lythraceae & Shrub & Custom, medicine, ornament & 3 & 0.5 & 41 \\
\hline Balik angin & $\begin{array}{l}\text { Mallotus paniculatus. (Lam.) } \\
\text { Müll.Arg. }\end{array}$ & Euphorbiaceae & Tree & Construction, firewood & 2 & 0.5 & 28 \\
\hline $\begin{array}{l}\text { Cemetir/Tembele } \\
\text { kan }\end{array}$ & Lantana camara $\mathrm{L}$ & Verbenaceae & Tree & Medicine & 1 & 0.4 & 36 \\
\hline Leban & Vitex pinnata $\mathrm{L}$ & Lamiaceae & Tree & Construction, firewood & 2 & 0.4 & 25 \\
\hline Johar & $\begin{array}{l}\text { Senna siamea (Lam.) H.S. Irwin + } \\
\text { Barneby }\end{array}$ & Fabaceae & Tree & Construction, firewood & 2 & 0.4 & 36 \\
\hline Daun sesiap & Ficus septica Burm.f & Moraceae & Tree & Medicine & 1 & 0.4 & 33 \\
\hline Kagas/Gharu & Aquilaria malaccensis Lamk. & Thymelaeaceae & Tree & Construction, firewood & 2 & 0.3 & 28 \\
\hline Kayu Angit & Clausena excavata Burm. F. & Rutaceae & Tree & Firewood, medicine & 2 & 0.3 & 30 \\
\hline Gelam & Syzygium sp. & Myrtaceae & Tree & Construction, firewood & 2 & 0.2 & 14 \\
\hline Kemutun & $\begin{array}{l}\text { Cratoxylon formosum Benth \& } \\
\text { Hook.f. ex Dyer. }\end{array}$ & Hypericaceae & Tree & Construction, firewood, medicine & 3 & 0.2 & 12 \\
\hline
\end{tabular}




\begin{tabular}{|c|c|c|c|c|c|c|c|}
\hline Semanik & Ixonanthes icosandra Jack. & Ixonanthaceae & Tree & Firewood, medicine & 2 & 0.1 & 12 \\
\hline Sirih & Piper betle L. & Piperaceae & Climber & Coloring, food, medicine, ornament & 4 & NA & NA \\
\hline $\begin{array}{l}\text { Alpukat/jambu } \\
\text { mentega }\end{array}$ & Persea americana Mill. & Lauraceae & Tree & Firewood, food, medicine & 3 & NA & NA \\
\hline Jambu air & Syzygium aqueum (Burm.f.) Alston. & Myrtaceae & Tree & Firewood, food, medicine & 3 & NA & NA \\
\hline Jarak abang & Jatropha gossypifolia $\mathrm{L}$ & Euphorbiaceae & Shrub & Hedge, medicine, ornament & 3 & NA & NA \\
\hline Mbacang & Mangifera foetida Lour. & Anacardiaceae & Tree & Construction, firewood, food & 3 & NA & NA \\
\hline Pisang & Musa sp. & Musaceae & Shrub & Custom, food, medicine & 3 & NA & NA \\
\hline Seris & Muntingia calabura $\mathrm{L}$. & Muntingiaceae & Tree & Firewood, food, medicine & 3 & NA & NA \\
\hline Daup putih & Bauhinia acuminata $\mathrm{L}$. & Fabaceae & Tree & Medicine, ornament & 2 & NA & NA \\
\hline Kandis & Garcinia dioica Blume & Clusiaceae & Tree & Firewood, food & 2 & NA & NA \\
\hline Kayu Bawang & Dysoxylum mollisimum Blume & Meliaceae & Tree & Construction, firewood & 2 & NA & NA \\
\hline Kayu Belalang & Dysoxylum arborescens (Blume) Miq. & Meliaceae & Tree & Firewood, medicine & 2 & NA & NA \\
\hline Kayu tulang & Euphorbia tirucalli $\mathrm{L}$. & Euphorbiaceae & Shrub & Medicine, ornament & 2 & NA & NA \\
\hline Mengkudu & Morinda citrifolia $\mathrm{L}$. & Rubiaceae & Tree & Food, medicine & 2 & NA & NA \\
\hline $\begin{array}{l}\text { Pegagan/kaki } \\
\text { kudo }\end{array}$ & Centella asiatica (L.) Urban & Apiaceae & Herb & Food, medicine & 2 & NA & NA \\
\hline Rotan getah & $\begin{array}{l}\text { Doemonorops angustifolia (Griff) } \\
\text { Mart. }\end{array}$ & Arecaceae & Palm & Food, handycraft & 2 & NA & NA \\
\hline Rotan kesur & Calamus ornatus Blume & Arecaceae & Palm & Food, handycraft & 2 & NA & NA \\
\hline Tupak & Baccaurea brevipes Hook.F & Phyllanthaceae & Tree & Firewood, food & 2 & NA & NA \\
\hline Ubi hitam & Dioscorea esculenta (Lour) Burkill & Dioscoreaceae & Climber & Food, medicine & 2 & NA & NA \\
\hline Belai banglai & Zingiber purpureum Roscoe. & Zingeberaceae & Herb & Medicine & 1 & NA & NA \\
\hline Karet/para & Hevea brasiliensis Müll.Agr. & Euphorbiaceae & Tree & Firewood & 1 & NA & NA \\
\hline Kayu Gambo & Unidentified & & Tree & Firewood & 1 & NA & NA \\
\hline Nuing & Ficus hispida L.f. & Moraceae & Tree & Medicine & 1 & NA & NA \\
\hline Pepulut & Urena lobata $\mathrm{L}$ & Malvaceae & Shrub & Medicine & 1 & NA & NA \\
\hline $\begin{array}{l}\text { Rumput angit/ } \\
\text { bandotan }\end{array}$ & Ageratum conyzoides L. & Asteraceae & Herb & Medicine & 1 & NA & NA \\
\hline Rumput babi & Cyanthillium cinereum (L.) H. Rob. & Asteraceae & Shrub & Medicine & 1 & NA & NA \\
\hline
\end{tabular}

Note: NA: not available (not shown to respondents)

Table 2. The ability of respondents to identify plant names.

\begin{tabular}{lc}
\hline Number of respondents & Ability to identify plants (\%) \\
\hline 6 & $\geq 90$ \\
14 & $80-89$ \\
16 & $70-79$ \\
17 & $60-69$ \\
4 & $51-59$ \\
6 & $41-49$ \\
0 & $31-39$ \\
1 & 28 \\
& Average ability to identify plants $=70.5 \%$ \\
\hline
\end{tabular}

Table 3. The percentage of respondents knowing the types of plant uses

\begin{tabular}{lc}
\hline Types of uses & \% of respondents knew \\
\hline Food & 98 \\
Medicine & 77 \\
Construction & 57 \\
Handycraft & 42 \\
Firewood & 37 \\
Hedge & 13 \\
\hline
\end{tabular}

\section{The knowledge of plant names and uses}

No respondent could identify all the 50 plant species in the photographs, but six of them could identify $\geq 90 \%$ of the plants. On average, they could recognize $70 \%$ of the plants and only one respondent had little knowledge of plant names, which was $28 \%$ (Table 2). Six species, namely, coconut, bamboo, jackfruit, manggo, sugar cane, and pandanus palm, were successfully identified by all respondents, fourten other species by more than $90 \%$ respondents and only 15 species were recognized by less than $40 \%$ respondents (Table 1 ). The identifiability of a plant had possitive correlation with its use value, and the correlation was strong (Table 4).

The knowledge of plant names among villagers in this study was higher than that among students of forestry in Bengkulu city, just $10 \mathrm{~km}$ from the study site, who could identify less than $60 \%$ of tree names in their campus (Wiryono and Nurliana 2011). It was likely that villagers in this study had more intensive interaction with the plants than the university students. Local knowledge of plants in rural area is the results of long and intimate interaction between people and their surrounding flora in search of food, medicine and other daily needs for their survival and this knowledge is passed from generation to generation (Pilgrim et al. 2008).

Almost all respondents (98\%) recognized the dietary use of edible plants, and majority respondents recognized the medicinal use of medicine plants $(77 \%)$ and constructional use of plants (57\%) (Table 3). Food and medicine are the most important need for human survival, so it is logical that most respondents knew the dietary and medicinal uses of plants.

In this study, key informants who were medicine men recognized more plants for medicine than for food, while respondents recognized more dietary use than medicinal use of plants. In an interesting study, Vandebroek and Balick (2012) found that young people of Dominican Republic who have migrated to New York City, far from their home country, maintained their knowledge of plants used for food and medicine simultaneously. 


\section{Factors affecting botanical knowledge Gender}

The knowledge of plant names was positively correlated with the knowledge of plant uses and the correlation was strong, meaning that respondents knowing more about the plant names also knew more about the plant uses (Table 4). The knowledge of plant names and uses was not affected by gender. On average, male respondents correctly identified $70 \%$ of the plants and females $71 \%$, and there was no difference on t-test. The average number of plant uses mentioned by males was 49 and by females 52, but this was not significant either.

Previous study (Wiryono and Nurliana 2011) also showed that gender did not affect knowledge of plants among forestry students in Bengkulu. Likewise, in Parnaíba Delta Environmental Protection Area, Brazil, Sousa et al. (2012) did not find any effect of gender on the knowledge of plant diversity.

\section{Age and time spent in garden}

The regression analyses showed that knowledge of plant names as well as plant uses was highly significantly correlated positively with ages, meaning that older people had more knowledge than the younger one, although the correlation was not strong (Table 4). The results of this study confirmed other studies that younger generation had less TEK than the older ones (Quinlan and Quinlan 2007; Sousa et al. 2012; Saynez-Vaquest et al. 2016). The loss of TEK among the youth is often attributed to cultural changes due to economic development (Pilgrim et al. 2008), modernization and globalization (Brosi et al. 2007; Ramirez et al. 2007; Turner and Turner 2008). With modernization younger people may be allienated from their environment and consequently lose their knowledge of nature. Pergams and Zaradic (2006) and Pergams and Zaradic (2008) had shown that the visit to the US parks had decreased drastically due to the emergence of electronic entertainment. The farmers of Doñana, Spain, lost their TEK because the TEK system had been replaced by modern knowledge and the farming system had been affected much by mechanization and market economy (Gómez-Baggethun and Reyes-Garcia 2013)

In our study, the time spent for electronic entertainment was not correlated with knowledge of plant names and uses, but the time spent in garden was significantly correlated positively with the knowledge of plants and the time spent in the garden was also correlated positively with ages (Table 4). So, in our study, older people visited garden more often than the younger generation. Similarly, Kai et al. (2014) also found that in Mengsong Township, Xishuangbanna, China, the elders visited forest more often than the youth, and so older people were better able to name birds at the species level.

We can assume that it is the decline in interaction with nature that causes the TEK loss and not the modernization or economic development itself. Furusawa (2009) studying in Solomon Islands concluded that modernization was not directly related to TEK loss. Gómez-Baggethun and ReyesGarcia (2013) from their study in Bolivia and Spain also concluded that response to globalization depends on the
TEK system held by the small societies. They found that the Tsimane' in Bolivia managed to maintain their TEK because it was still the basis of their livelihood and they still practiced farming and sold products in a traditional way. In another study, Vandebroek and Balick (2012) found that young people from the Dominican Republic, who had moved to New York City maintained the knowledge of food medicines because they continued consuming the food.

\section{Education}

Table 5 implied that level of education had no effect on the knowldege of plants. The higher knowledge of respodents unfinishing school than the others was likely due to their ages, because they were old people, 49-63 years old. However, other studies in Caribbean (Quinlan and Quinlan 2007) and in Mexico (Saynez-Vaquez et al. 2016) found that knowledge of plants was negatively correlated with formal education level. Saynez-Vaquez et al. (2016) explained that Zapotecs children in Mexico who attended school did not have much time to accompany and help their parents collecting plants and they lost their skill in their mother tongue, the language of their TEK, because the schools used different language.

Table 3. Results of regression analyses showing correlation among variables

\begin{tabular}{lll}
\hline Variables correlated & Sig. & R \\
\hline $\begin{array}{l}\text { Independent variables (X1, X2): age of } \\
\text { respondents, time spent in garden }\end{array}$ & 0.000 & 0.511 \\
$\begin{array}{l}\text { Dependent variable (Y1): knowledge of plant } \\
\text { names }\end{array}$ & & \\
$\begin{array}{l}\text { X1, X2: Age of respondents, time spent in } \\
\text { garden }\end{array}$ & 0.000 & 0.640 \\
$\begin{array}{l}\text { Y2: Knowledge of plant uses } \\
\text { X3: Time spent for electronic entertainment }\end{array}$ & 0.264 & 0.144 \\
$\begin{array}{l}\text { Y1: Knowledge of plant names } \\
\text { X3: Time spent for electronic entertainment }\end{array}$ & 0.371 & 0.116 \\
$\begin{array}{l}\text { Y2: Knowledge of plant uses } \\
\text { X4: Use value of plants }\end{array}$ & 0.000 & 0.722 \\
$\begin{array}{l}\text { Y3: The identifiablity of plant } \\
\text { X: Age of respondents }\end{array}$ & 0.053 & 0.24 \\
$\begin{array}{l}\text { Y: Time spent in garden } \\
\end{array}$ & & \\
\end{tabular}

Note R: correlation coefficient

Table 5. The level education and the knowledge of plant names and uses.

\begin{tabular}{lcc}
\hline Education level & $\begin{array}{c}\text { \% of plant names } \\
\text { correctly } \\
\text { identified }\end{array}$ & $\begin{array}{c}\text { The number of } \\
\text { plant uses known }\end{array}$ \\
\hline Not finishing & & \\
Elementaray school & 41 & 66 \\
Elementary School & 34 & 50 \\
Junior High school & 35 & 47 \\
Junior High School & 34 & 49 \\
College & 34 & 47 \\
\hline
\end{tabular}

Note: those unfinishing elementary school were $49-63$ years old 
In conclusion, the villagers used 75 plant species for ten categories, namely medicine, firewood, food, construction, ornament, handycraft, hedge, custom, forage, and food coloring. On average, respondents could identify $70 \%$ of plants shown to them. The local botanical knowledge was positively correlated with age and time spent in the garden, and time spent in the garden was positively correlated with age. The decrease of botanical knowledge among the youth was presumably due to the less time they interacted with plants in the garden than the older people.

To get a better result of the study, we should have investigated how villagers acquired botanical knowledge, so we would have known for sure, what caused the decline of that knowledge among the youth. Based on this information, we could plan learning activities involving the local people, young and old, collecting botanical data from their environment. Engagement in this project may increase ecological awareness and therefore may help preserve the LEK among the youth.

\section{ACKNOWLEDGEMENTS}

We thank M. Fajrin Hidayat for making a map of study site for this article and for Dr. Irnad for providing the statistical software. We also offer sincere gratitude to the reviewer who gave valuable comments and suggestion for the improvement of this article.

\section{REFERENCES}

Albuquerque UP, Lucena RFP, Monteiro JM, Florentino ATN, Almeida CFCBR. 2006. Evaluating two quantitative ethnobotanical techniques. Ethnobot Res Appl 4: 051-060.

Brosi BJ, Balick MJ, Wolkou R, Lee R, Kostka M, et al. 2007. Cultura erosion and biodiversity: Canoe-making knowledge in Pohnpei, Micronesia. Cons Biol 21: 875-879.

Charnley S, Fischer AP, Jones ET. 2007. Integrating traditional and local ecological knowledge into forest biodiversity conservation in the Pacific Northwest. For Ecol Manag 246: 14-28.

Drew JA, Henne AP. 2006. Conservation biology and traditional ecological knowledge: integrating academic disciplines for better conservation practice. Ecol. Soc. 11 (2): 34.

Furusawa T. 2009. Changing ethnobotanical knowledge of the roviana people, Solomo Islands: quantitative approach to its correlation with modernization. Hum Ecol 37: 147-159.

Gómez-Baggethun E, Reyes-García V. 2013. Reinterpreting change in traditional ecological knowledge. Hum Ecol 41: 643-647.

Hariyadi B, Ticktin T. 2012. Uras: Medicinal and ritual plants of Serampas, Jambi Indonesia Ethnobot Res Appl 10: 133-149.

Kai Z, Woan TS, Jie L, Goodale E, Kitajima K, et al. 2014. Shifting baselines on a tropical forest frontier: Extirpations drive declines in local ecological knowledge. PLoS ONE 9 (1): e86598. doi:10.1371/journal.pone.0086598

Okubo S, Parikesit, Harashina K, Muhammad D et al. 2010. Traditional perennial crop-based agroforestry in West Java:the trade off between on-farm biodiversity and income. Agrofor Syst 80: 17-31.

Pamungkas RN, Indriyani S, Luchman Hakim L. 2013. The ethnobotany of homegardens along rural corridors as a basis for ecotourism planning: a case study of Rajegwesi village, Banyuwangi, Indonesia.
Journal of Biodiversity and Environmental Sciences (JBES). 3 (8): 60-69.

Pergams ORW, Zaradic PA. 2006. Is the love of nature in the US becoming the love of electronic media? 16-year downtrend in national park visits explained by watching movies, playing video games, internet use and oil prices. J Environ Manag 80 (4): 387-39.

Pergams ORW, Zaradic PA. 2008. Evidence for a fundamental and pervasive shift away from nature-based recreation. Proc Natl Acad Sci USA 105 (7): 387-393.

Pilgrim SE, Cullen LC, Smith DJ, Pretty J. 2008. Ecological knowledge is lost in wealthier communities and countries. Environ Sci Technol 42 (4): 1004-1009.

Quinlan MB, Quinlan RJ. 2007. Modernization and medicinal plant knowledge in a Caribbean horticultural village. Med Anthropol Q 21 (2): 169-192.

Rahayu M, Rugayah. 2010. Local knowledge and utilization of plants by local communities Kabaena Island, Southeast Sulawesi. Berita Biologi 10 (1): 67-75.

Ramirez CR. 2007. Ethnobotany and the loss of traditional knowledge in the 21 st century. Ethnobot Res Appl 5: 245-247.

Rathore S, Tiwari JK, Zubair A Malik. 2015. Ethnomedicinal survey of herbaceous flora traditionally used in health care practices by inhabitants of Dhundsir Gad watershed of Garhwal Himalaya, India. Global J Res Med Plants \& Indigen Med 4 (4): 65-78.

Saxon E, Roquemore 2111. Palm Oil in Boucher D, Elias P, Lininger K, et al (eds.) 2011. The root of the problem. What is the driving force of tropical deforestation today? Tropical Forest and Climate Initiative. Union of Concerned Scientists.

Saynes-Vásquez A, Vibrans H, Vergara-Silva F, Caballero J. 2016. Intracultural differences in local botanical knowledge and knowledge loss among the Mexican Isthmus Zapotecs. PLoS ONE 11 (3): e0151693. doi:10.1371/journal.pone.0151693

Setalaphruk C, Price LL. 2007. Children's traditional ecological knowledge of wild food resources: a case study in a rural village in Northeast Thailand. J Ethnobiol Ethnomed 3: 33-44.

Sousa RS, Hanazaki N, Lopes JB, de Barros RFM. 2012. Are gender and age important in understanding the Distribution of Local Botanical Knowledge in Fishing Communities of the Parnaíba Delta EnvironmentalProtection Area? Ethnobot Res Appl 10: 551-559.

Susiarti S. 2015. Local people knowledge on medicinal plants in Seram Island, Moluccas. Procedings of Nasional Seminar Indonesian Biodiversity Society 1 (5): 1083-1087.

Syamsiah, Hiola SF, Mu'nisa A, Jumadi O. 2016. Study on medicinal plants used by the ethnic Mamuju in West Sulawesi, Indonesia.. J Trop Crop Sci 3 (2): 42-48.

Tongco MD. 2007. Purposive sampling as a tool for informant selection. Ethnobot Res Appl 5: 147-158.

Turner NJ, Turner KL. 2008. "Where our women used to get the food": Cumulative effects and loss of ethnobotanical knowledge. Botany 86 : 103-115.

Vandebroek I, Balick MJ. 2012. Globalization and loss of plant knowledge: challenging the paradigm. PLoS ONE 7 (5): e37643. doi:10.1371/journal.pone.0037643.

Wardah. 2003. Pemanfaatan keanekaragaman sumberdaya tumbuhan oleh masyarakat Badudy Dalam sekitar Gunung Kendeng Selatan, Kabupaten Lebak, Banten. Berita Biologi 5 (6): 679-689.

Wiryono, Nurliana S. 2011. The knowledge of Bengkulu University's forestry students of tree diversity in their campus. Nusantara Biosicence 22: 98-103.

Wiryono, Lipranto. 2013. The diversity of locally useful species Batu Ampar village near Bukit Raja Mandara protected forest area in South Bengkulu District. Jurnal Manusia dan Lingkungan 20 (2): 119-127.

Wiryono, Puteri VNU, Senoaji G. 2016. The diversity of plant species, the types of plant uses and the estimate of carbon stock in agroforestry system in Harapan Makmur Village, Bengkulu, Indonesia. Biodiversitas 7 (1): 249-255.

Zank S, Hanazaki N. 2017. The coexistence of traditional medicine and biomedicine: A study with local health experts in two Brazilian regions. PLoS One 12 (4): e0174731. Doi: 10.1371/journal.pone.0174731 